\title{
EKOKRITIK DALAM CERPEN INDONESIA MUTAKHIR
}

\author{
Afry Adi Chandra \\ SMK Negeri 1 Udanawu, Kabupaten Blitar \\ Email: afryadichandra@yahoo.com
}

\begin{abstract}
Abstrak
Karya sastra sebagai sarana pembawa misi kemanusiaan memiliki peranan positif terhadap perkembangan dunia dalam konteks kehidupan bermasyarakat. Cerpen sebagai salah satu jenis karya sastra, di masa kini juga semakin berkembang. Isu-isu terkait lingkungan menjadi bagian yang tak terpisahkan dalam perkembangan karya cerpen di Indonesia. Ekokritik merupakan bahasan yang mengkhususkan diri dalam upaya "menyelami" keterkaitan antara karya sastra dengan fenomena lingkungan hidup. Penelitian ini berfokus pada kajian karya sastra cerpen yang mengangkat isu-isu tentang lingkungan hidup masa kini di Indonesia. Gambaran hasil yang didapat, bahwa teknik/gaya penceritaan maupun pesan moral yang diangkat dalam beberapa cerpen bertemakan lingkungan semakin variatif. Peluang ini dapat dimanfaatkan secara maksimal sebagai jalan penyelamatan lingkungan sekaligus penyelamatan karya sastra, cerpen utamanya. Karya sastra (cerpen) dapat menjadi "angin segar" bagi kedua hal tersebut. Apalagi fenomena lingkungan yang terjadi di masyarakat akhir-akhir ini amat mengkhawatirkan kelangsungan makhluk hidup di masa mendatang.
\end{abstract}

Kata kunci: ekokritik, cerpen, kritik sastra

\begin{abstract}
Literary work as a means of a humanitarian mission having the role of the rise of the in the context of social life. Short stories as one kind of literary work, in present-day also keeps growing. Various issues related to the environment for an integral part in the development of the short stories in Indonesia. Ecocriticism is subjects who specializes in an effort to "plumbed" the links between literary work to the environment. This research focus on study literary work short stories who raised issues of on environment today in Indonesia. The image of the results obtained, that engineering telling / style and a moral message taken up in a few short stories titled environment
\end{abstract}


increasingly more varies. This opportunity can be used in full as a saving the environment and rescue literary work, short stories main. Literary work ( short stories ) can be "wind fresh" for both. Moreover environmental phenomenon that happens in society the recent very alarming directness of creatures in the future.

Keywords: ecocriticism, short stories, and literary work

\section{PENDAHULUAN}

Sastra adalah kemanusiaan. Sastra juga bisa menjadi alat perjuangan bagi manusia-manusia tertindas untuk menendang kekuasaan yang menidurinya dengan semena-mena (Kresna, 2001:26). Perspektif ini muncul sebagai sebuah gagasan yang berdasar. Bagaimana tidak? Sastra muncul serta tumbuh berkembang seiring perkembangan arus zaman. Berbicara arus zaman, maka tidak akan jauh dari nilai-nilai tentang kemanusiaan. Sastra hadir sebagai representasi nilai-nilai kehidupan yang ada di sekitar lingkungan manusia. Entah itu terejawantahkan dalam bentuk nilai sosial, keagamaan, budaya, maupun isu tentang lingkungan. Membahas sastra, berarti membahas pula ihwal pengarang/penulis serta masyarakat pembaca/penikmatnya. Melalui tangan terampil sang pengarang, karya sastra di Indonesia mampu berkembang produktif dan semakin variatif. Sisi produtikvitas pencipataan karya menjadi salah satu jalan menumbuhkan keberagaman karya sastra dengan beragamnya ide yang ada. Kontribusi positif ini menjadi peluang terbuka lebar dalam mengembangkan ragam karya sastra di Indonesia. Apalagi saat ini, penulis-penulis muda berbakat sudah mulai bermunculan di berbagai pelosok nusantara. Hadir dengan ragam karakter unik yang melekat pada tiap karya-karya sastranya. Setelah pengarang/penulis, yang tak kalah menarik untuk dibahas adalah peran aktif pembaca dalam mengkritisi perkembangan sastra di Indonesia. Tak mampu 
dipungkiri, karya sastra sanggup tumbuh pun berkembang juga lantaran kehadiran pembaca/penikmat yang cerdas. Hadirnya pembaca/penikmat sastra mampu memberikan koreksi atas pencipataan karya dari berbagai sastrawan di Indoensia, utamanya. Bahasan tentang koreksi dari para pembaca/penikmat inilah yang nanti akan begitu melekat dengan aktivitas kritik sastra.

Isu mengenai lingkungan pada dekade ini semakin santer terdengar di beragam media. Peningkatan aktivitas manusia dalam berbagai aspek kehidupan menjadi pemicu isu tentang lingkungan hidup makin marak terdengar. Fenomena ini menjadi semacam "bom waktu" yang di kemudian hari dapat mendatangkan musibah bagi kelangsungan hidup manusia. Seiring gencarnya para aktivis lingkungan menyerukan suara terkait upaya penyelamatan lingkungan. Di sisi lain, sikap masyarakat justru semakin tidak sadar dengan pentingnya kelestarian lingkungan di masa kini pun mendatang. Dikotomi ini sungguhlah berkontradiksi. Padahal lingkungan dapat menjadi salah satu elemen pemicu munculnya berbagai permasalahan, baik segi sosial maupun kesehatan. Hal tersebut apabila dibiarkan berlarut-larut, tak mustahil keberlangsungan hidup seluruh makhluk hidup termasuk manusia akan terancam.

Di atas sudah dipaparkan, bahwa bicara sastra, bicara pula tentang nilai-nilai kemanusiaan. Sastra begitu lekat dengan kemanusiaan. Isu-isu mengenai lingkungan hidup juga menjadi salah satu tema dari nilai kemanusiaan dalam sastra. Ekokritik memberikan perhatian terhadap hubungan timbal balik antara karya sastra dengan lingkungan hidup, termasuk hubungan dengan realitas sosial budaya dan fisik, yang biasanya menjadi perhatian dalam ekologi (Endraswara, 2016:viii). Pada perkembangannya, tak hanya hubungan timbal balik antara sastra dengan 102 | ISSN: 22477-5150, e-ISSN: 2549-2195 http://journal.unesa.ac.id/index.php/jpi 
lingkungan saja, namun keterkaitan nilai sosial budaya juga turut mewarnai perkembangan karya sastra, termasuk di Indonesia. Keragaman sosial budaya yang dimiliki bangsa Indonesia menjadi komposisi yang semakin menarik apabila ditampilkan dalam wujud karya sastra. Syaratnya, isu-isu terkait lingkungan hidup haruslah tetap menjadi sorotan utama dalam penciptaan karya. Terkait nilai sosial budaya, hanyalah sebagai "bumbu penyedapnya". Tak dapat dipungkiri, permasalahan lingkungan memang makin mengkhawatirkan. Maka dari itu, kehadiran sastra dapat menjadi manifestasi dalam upaya penyelamatan lingkungan hidup.

Bahasan antara sastra dengan lingkungan maupun sebaliknya merupakan khazanah kesastraan Indonesia. Mengingat Indonesia kaya akan limpahan hasil alam. Keuntungan besar inilah yang dapat dimanfaatkan sebagai sumber penulisan sastra ekologis. Kaitan sastra dengan ekologi disebut sastra ekologis (Endraswara, 2016: 2). Apalagi dibalik kekayaan alam tersebut, banyak bermunculan sikap manusia yang tak mengindahkan kelestarian lingkungan, dari merusak; mencemari; mengotori; sampai mengeksploitasi alam. Sikap tersebut sangatlah disayangkan. Apalagi kekayaan alam adalah salah satu modal kemajuan suatu bangsa. Dalam pencipataan suatu karya sastra, apalagi yang berbalut dengan fenomena lingkungan, pastilah terdapat pesan ekologis yang ingin disampaikan kepada para pembaca/penikmatnya. Gagasan, ide, kritikan, maupun amanat merupakan bagian dari pesan ekologis tersebut. Pesan ekologis ini pun pada perkembangannya juga dapat terbalut dalam nilai agama, sosial, serta budaya. Karena itu, karya sastra di Indonesia akan semakin variatif.

Cerpen sebagai salah satu genre karya sastra, pada belakangan ini cukuplah berkembang. Cerpen memberikan ruang terhadap para penulis 
sastra menyampaikan perspektifnya ihwal dunia, baik berwujud fiksi maupun nonfiksi. Cerpen harus dipahami oleh khalayak pembaca seluasluasnya (Sarumpaet dan Budianta, 2010:128). Sastra adalah kemanusian. Sastra menjadi wahana untuk menjunjung misi tentang kemanusiaan. Misi kemanusiaan tersebut salah satunya adalah isu lingkungan. Ekokritik menjadi bahasan penting untuk ditelaah serta dikritisi secara komprehensif. Keterkaitan antara sastra dengan lingkungan ini menjadi "bahan segar" dalam upaya memahami perkembangan ekokritik, utamanya pada lingkup sastra Indonesia. Seiring perkembangan zaman, karya sastra bergenre lingkungan menjadi semakin variatif kemunculannya. Baik dari segi ide, alur cerita, pengembangan tokoh dan penokohan, sudut pandang, maupun pesan moral yang ingin disampaikan penulis kepada para penikmatnya. Beberapa sastrawan Indonesia mutakhir yang menghasilkan karya cerpen dengan perspektif ekokritik antara lain S.Prasetyo Utomo; Adi Zamzam; Tjak S.Parlan; Muliadi G.F; serta Manaf Maulana. Para penulis tersebut acapkali muncul dengan karya-karya cerpennya di berbagai media massa Indonesia. S.Prasetyo Utomo dengan cerpen Pertunjukan Hari Ketujuh; Adi Zamzam dengan cerpen Rob; Tjak S.Parlan dengan cerpen Pergi ke Bukit; serta Muliadi G.F dengan cerpen Al-Fatihah untuk Pohon-Pohon. Media massa yang menanungi karya-karya cerpen yang membahas ihwal ekokritik tersebut diantaranya Kompas, Republika, Jawa Pos, serta Tempo. Dari segi penyampaian cerita; perspektif yang dipilih; alur; maupun pesan moral yang disampaikan, masing-masing penulis memiliki kekhasan yang melekat. Hal tersebut sangat berkontribusi positif dalam memperkaya khazanah cerpen di Indonesia, terutama yang menjadikan isu lingkungan menjadi sorotan utama. 
Penelitian ini bertujuan untuk mengulas serta mengkritisi pelbagai karya sastra cerpen Indonesia mutakhir yang termuat di media massa. Media adalah pesan. Media yang efektif meihat beberapa bentuk konten yang diperlakukan sebagai pesan (Dewi, 2015:3). Akses masyarakat yang lebih mudah dalam menjangkau media massa menjadi alasan utama, mengapa cerpen dari berbagai sumber media massa tersebut dipilih untuk dikritisi. Dibalik manfaatnya dalam menyampaikan berbagi ragam berita, media massa juga punya kontribusi lain, yaitu menggerakkan masyarakat untuk berliterasi sastra (cerpen). Nilai moral yang tersampaikan lewat karya sastra (cerpen) tersebut dapat menjadi sarana pendidikan masyarakat melalui perspektif sastra. Sehingga pada akhirnya, masyarakat akan semakin memahami pentingnya kelestarian lingkungan melalui karya-karya sastra, semacam cerpen.

\section{METODE}

Jenis penelitian ini adalah deskriptif kualitatif. Penelitian kualitatif adalah penelitian yang bermaksud untuk memahami fenomena tentang apa yang dialami oleh subjek penelitian misalnya, perilaku, persepsi, motivasi, tindakan, dan lain-lain secara holistik dan dengan cara deskripsi dalam bentuk kata-kata dan bahasa, pada suatu konteks khusus yang alamiah dan dengan memanfaatkan berbagai metode alamiah (Moleong, 2005:6). Pendekatan yang dipergunakan untuk melakukan penelitian ini adalah pendekatan ekokritik. Sastra selalu berkaitan dengan manusia, salah satu komponen didalamnya yakni lingkungan. Sastra adalah cermin keadaan lingkungan (Endraswara, 2016: viii).

Melalui pendekatan tersebut, peneliti akan mengkaji keterkaitan antara karya sastra cerpen Indonesia mutakhir dengan lingkungan. 
Mutakhir disini dimaknai sebagai karya satra berwujud cerpen yang terbaru/paling baru, terutama yang mengangkat isu ekokrtitik di dalam isi ceritanya. Sumber data dalam penelitian ini adalah teks sastra dalam bentuk cerpen Pertunjukan Hari Ketujuh karya S.Prasetyo Utomo; Adi Zamzam dengan cerpen Rob; Pergi ke Bukit karya Tjak S.Parlan; serta Muliadi G.F dengan cerpen Al-Fatihah untuk Pohon-Pohon. Data yang dipergunakan adalah teks sastra (cerpen) dengan berfokus pada aspek ekokritik (keterkaitan antara sastra dengan lingkungan). Teknik pengumpulan data dengan triangulasi (sumber, metode, teori, serta peneliti). Analisis data bersifat deskriptif kualitatif, dengan mengkaji serta mendeksripsikan aspek ekokritik yang terdapat dalam teks cerpen Pertunjukan Hari Ketujuh; Rob; Pergi ke Bukit; serta Al-Fatihah untuk Pohon-Pohon. Hasil disajikan dalam bentuk teks narasi yang menjelaskan aspek lingkungan berbasis karya sastra cerpen.

\section{HASIL DAN PEMBAHASAN}

\section{Ekokritik: Memahami Lingkungan melalui Sastra}

Manusia beserta lingkungannya adalah sumber penciptaan karya sastra. Sastra tak akan jauh dari kebudayaan manusia. Salah satu elemen pendukung budaya adalah lingkungan. Elemen satu ini sangat berpengaruh terhadap perkembangan kebudayaan manusia. Wujud dari kebudayaan tersebut diantaranya adalah karya sastra. Ragam karya sastra yang tumbuh di masyarakat menjadi kajian yang amat menarik. Terlebih, keunikan perspektif yang dipergunakan dalam mendeskripsikan masing-masing kebudayaan. Indonesia merupakan simbol keberagaman budaya di dunia. Semua manusia merupakan aktor kebudayaan karena manusia bertindak dalam lingkup kebudayaan (Liliweri, 2002:7). Sebagai negara kepulauan, 
letak geografis Indonesia memiliki peranan penting dalam membentuk keragaman tersebut. Apabila dikelola dengan baik, ini merupakan rahmat. Begitu pula sebaliknya, sikap egosentris yang tinggi serta intoleran, dapat menjadi sumbu pemicu munculnya beragam pergolakan karena masalah SARA (suku, agama, dan ras).

Sikap intoleran juga dapat muncul dalam pelbagai aspek kehidupan. Salah satunya adalah intoleran dalam hal pemanfaatan lingkungan. Lingkungan adalah bagian dari ekosistem yang diperuntukkan sebesar-besar kehidupan. Poin ini tak lantas menjadi alasan pengeksploitasian alam secara berlebihan. Aktivitas tersebut apabila terus berjalan. Lambat laun, lingkungan alam tak mampu menjadi penyeimbang ekosistem. Hanya kerusakan serta beragam permasalahan sosial-budaya yang akan muncul ke permukaan.

Menghadapi fenomena tersebut, sastra hadir sebagai juru damai. Memberikan ruang terhadap kelangsungan hidup lingkungan di masa mendatang. sastra sebagai sarana penyampai isu-isu tentang etika lingkungan yang kadangkala luput dari perhatian. Etika lingkungan mempunyai tujuan praktis dan bukanlah sekadar merupakan uraian tentang tempat manusia dalam alam semesta atau pembenaran sistem etika yang disepakati di antara manusia (Drummond, 2006:75). Sastra mampu membawa permasalahan tentang lingkungan melalui "denyut bahasa". Sastra mampu menjadi alternatif untuk membelajarkan masyarakat mengenai pentingnya kelestarian lingkungan alam. Ekokritik merupakan kajian yang membahas hubungan antara sastra dengan lingkungan. Menurut Garrard (2004), ekokritik dapat membantu menentukan, mengeksplorasi, dan bahkan menyelesaikan masalah ekologi. Permaslahan 
lingkungan (ekologi) dari zaman ke zaman semakin kompleks. Permasalahan tersebut jelaslah memerlukan ancangan sistematis guna penyelesaiannya. Isu lingkungan memang bukan permasalahan yang mudah untuk dipecahkan. Stigma masyarakat yang kurang sadar akan pentingnya menjaga kelestarian lingkungan menjadi sumber permasalahan lingkungan bak "benang kusut". Maka dari itu, melalui ciri humanis yang melekat dalam sastra, diharapkan di masa mendatang kajian ekokritik akan semakin berkembang seiring dengan kemajuan pemahaman manusia tentang pentingnya lingkungan alam.

\section{Ekokritik dalam Cerpen Indonesia Mutakhir}

Pengkajian ekokritik menjadi hal yang menarik, apalagi isu tentang lingkungan makin sering didengungkan. Perkembangan warna karya sastra di Indonesia menjadi "bahan lezat" untuk dikaji, salah satunya melalui perspektif ekokritik. Karya sastra dan isu lingkungan di masa mutakhir ini, makin tumbuh pun berkembang pula. Beragam wujud karya sastra Indonesia semakin banyak yang didedikasikan oleh sang penulis sebagai sarana misi kemanusiaan. Upaya pelestarian lingkungan menjadi muatan moral yang ingin disampaikan oleh sang pencipta karya dalam misi kemunisiannya. Ini sungguh menjadi wujud konkret rasa kepedulian terhadap lingkungan melalui kendaraan sastra.

Berbicara kritik sastra, berarti tak akan jauh dari aktivitas menafsirkan serta memberikan penilaian terhadap karya sastra. Menurut Yudiono (1990: 21-22), kritik sastra ialah penilaian (penafsiran, penerangan, penghakiman) terhadap karya sastra. Jadi jelaslah, bahwa kritik sastra hanya akan mengupas karya, bukan membahas ihwal sang pencipta/penulisnya. Dalam penelitian ini, kajian kritik sastra dipergunakan untuk memberikan 
penilaian terhadap cerpen Indonesia mutakhir yang tergolong dalam ranah ekokritik. Salah satu cerpen tersebut adalah karya Adi Zamzam berjudul Rob. Cerpen ini pernah diterbitkan di media massa Kedaulatan Rakyat edisi 2 Juli 2017. Penulis cerpen Rob lahir di Jepara pada Januari 1982. Berbagai karya tersebar di beragam media masa. Sudut pandang cerita memilih tokoh Budi sebagai sentral penceritaan. Kisah Budi sebagai tokoh utama dalam cerpen yang mengalami konflik batin, sebagai akibat dari fenomena banjir rob di daerahnya yang tak pernah usai. Banjir telah menjadi sebuah kebiasaan yang mau tidak mau harus ia terima bersama warga lainnya. Semasa Bapak Budi masih hidup, beliaulah yang selalu memperjuangkan kesejahteraan warga desa, salah satunya dalam pembangunan sarana dan prasana milik desa.

Jika bukan karena bapaknya Budi, Tambakmulyo, Tambakrejo, Bandarharjo, hingga Bedono, takkan memiliki jembatan yang menghubungkannya dengan kampungkampung seberang yang dipisahkan oleh sungai yang menyimpan banyak kenangan itu...

"Bapakmulah yang jadi pentolannya. Lapor ke Bupati dan lalu meneruskannya ke Gubernur. Bahkan Pak Kades zaman itu tak seberani bapakmu" (Zamzam, 2017).

Daerah Tambakmulyo, Tambakrejo, Bandarharjo, sampai Bedono merupakan daerah pesisir utara Semarang. Daerah tersebut merupakan langganan banjir rob. Fenomena banjir rob di Semarang Utara menjadi perhatian bagi Adi Zamzam. la mengangkat cerpen berlatar banjir rob yang masih menjadi pekerjaan rumah bersama antara warga dengan pemerintah daerah. Melalui cerpen Rob, penulis menggunakan tokoh Budi sebagai sentral cerita. Bapak Budi diceritakan memiliki andil besar dalam 
pembangunan di desanya. la berperan aktif mengurus kesejahteraan warganya. Hal tersebut sungguh berkontradiksi dengan Pak Kades (Atmojo) yang notabene punya kuasa untuk mengatur serta menyejahterakan warganya. Salah satu wujud perjuangan Bapak Budi adalah dengan melibatkan diri secara aktif dalam usaha pembangunan jembatan didaerahnya. Sikap tersebut nyatanya malah membuat Pak Kades merasa tak menyukai perangai Bapak Budi. Alhasil ketika meninggal dunia, makam Bapak Budi diletakkan paling pinggir. Sebuah gambaran kebencian yang tak berdasar.

Di suatu senja, besar keinginan Budi menjenguk makam bapaknya. la berharap bisa segera membagikan kebahagian dengan sang bapak. Namun, banjir rob telah merendam pemakaman, termasuk makam Bapak Budi. Harapan itu sirna sudah. Banjir rob makin tak terkendali. Hal tersebut dapat dilihat dalam kutipan berikut.

"Iya. Dari omong-omong dengan Pak Kades kemarin. Tanah kan harus beli. Lihat, kita sampai capek ngurug kuburan ini. Mau sampai kapan, kalau robnya enggak pernah minggat?" sambil menunjuk beberapa makam yang sudah terendam, termasuk makam bapaknya Budi (Zamzam, 2017).

Meskipun warga sudah berulang kali mengurug tanah sekitar pemakaman agar lebih tinggi, namun banjir rob terus merendamnya berulang-ulang kali. Warga desa merasa benar-benar jengkel dengan banjir rob yang terus melanda. Aktivitas warga desa menjadi begitu terganggu.

Suasana seperti ini sebenarnya sudah terbayangkan sejak pertemuan dengan Lik Gunawan di Terboyo. Perihal Kali Sayung yang meluber ke mana-mana. Belum lagi dengan beberapa tempat di Semarang yang terendam rob. Terminal Terboyo tak bisa disinggahi. Jalan Kaligawe memerangkap ratusan kendaraan roda empat dalam antrean 
menjengkelkan. Tambakmulyo, Tambakrejo, Bandarharjo, hingga Bedono semakin tergenang. Konon, penyebabnya adalah bangunan-bangunan yang didirikan di kawasan yang semestinya menjadi tempat penampung rob (Zamzam, 2017).

Kesalahan manusia menjadi penyebab banjir rob yang tak pernah usai di daerah Semarang Utara. Sang penulis mendeskripsikan dengan jelas, dampak yang diakibatkan dari banjir rob yang kerap melanda. Nyatanya, fenomena kerusakan lingkungan sebagai sumber utama adalah sikap manusia yang tak bertanggung jawab. Pembangunan fisik yang terus berlanjut, ditambah lagi kurangnya pemahaman tentang analisis dampak lingkungan (amdal) menjadi penyebab banjir rob di Semarang Utara tersebut. Daerah resapan air yang harusnya menjadi penyangga/penampung air, beralih fungsi. Bangunan perumahan, pertokoan, sampai perindustrian, acapkali memang di bangun di daerah yang kurang tepat.

Pandangan Budi masih ngungun, mendapati teras rumah yang tergenang air sungai. Sebagian kepalanya berisi hitung-hitungan perkiraan tanah yang dibutuhkan untuk meninggikan teras rumah. Mengikuti jejak para tetangganya yang sudah gigih duluan melawan rob (Zamzam, 2017).

Meskipun banjir rob tak pernah selesai, tetapi ketahanan dan ketabahan warga desa masih saja terus terjaga. Mereka masih mampu bertahan hidup di atas gangguan rob yang amat sering merendam pemukiman warga. Hal tersebut dapat di lihat pada paragraf di atas. Tampak warga begitu gigih melawan banjir rob yang menggenangi rumah mereka. Besarnya biaya yang harus dikeluarkan menjadi kerugian tersendiri bagi warga. Fenomena 
tersebut memberikan pelajaran moral, bahwa akar permasalahan dari banjir rob merupakan kecerobohan manusia dalam pelaksanaan pembangunan pada suatu wilayah. Daerah penampung air memang sudah seyogyanya steril dari berbagai jenis bangunan. Dari berbagai kutipan cerpen di atas, memperlihatkan bahwa pemerintah juga belum bertindak maksimal atas bencana yang amat sering mendera warganya. Di sisi lain, usaha yang dilakukan warga sebatas penanganan sesudah terjadinya bencana, bukan upaya preventif. Pada akhirnya, cerpen ini memberikan pelajaran moral kepada masyarakat, bahwa kelestarian lingkungan merupakan tanggung jawab bersama. Sastra menjadi alat untuk menyampaikan pembelajaran moral akan pentingnya kelestarian lingkungan bagi kelangsungan umat manusia.

Cerpen kedua yang juga membahas tentang kajian ekokritik adalah Al-Fatihah untuk Pohon-Pohon karya Muliadi G.F. Harian Jawa Pos edisi 30 April 2017 pernah menayangkan cerpen ini. Berkisah tentang tokoh Akilah yang menganggap dirinya sebagai "teman" dari pohon-pohon. Sesuai dengan judul cerpen, isi cerita yang disampaikan mengadopsi isi surat $\mathrm{Al}$ Fatihah dari Al-qur'an. Surat tersebut terdiri atas tujuh ayat. Surat Alfatihah adalah induk dari Al-qur'an seluruhnya (Ummul Kitab), sehingga surat tersebut merupakan intisari dari Al-qur'an, yaitu mengandung pokokpokok: (1) akidah; (2) ibadah; (3) hukum-hukum; (4) janji dan ancaman; serta (5) kisah-kisah (Priyo, 2015). Sebuah cerpen yang cukup segar ide penceritaannya, karena menggabungkan aspek religiositas dengan ekologi. Pemahaman tentang arti penting pelestarian lingkungan melalui pemanfaatan aspek religi. 
Dengan menyebut nama Allah yang Maha Pengasih lagi Maha Penyayang.

Baru sepuluh tahun hidup saya, tapi saya sudah mengalami banyak kehilangan. Saya bicara soal pohon-pohon di halaman. Ketika saya sudah bisa menyadari apa-apa dengan jelas, dan ibu atau bapak atau nenek atau kakak sering membawa saya main-main di halaman, pohonlah yang langsung saya sentuh. Saya tidak takut, tidak. Entah kenapa (Muliadi, 2017).

Kisah cerpen diawali dengan terjemahan ayat pertama surat AlFatihah. Dalam kajian islam, mengucap asma Allah sebelum melakukan kegiatan tertentu, akan mendatangkan kemaslahatan bagi yang menjalankan. Ayat tersebut menjadi semacam harapan, agar apapun yang akan dijalani dapat berjalan dengan baik, lancer, serta mendapatkan rida dari-Nya. Tokoh Saya (Akilah) menjadi pencerita dalam penggunaan sudut pandang di cerpen karangan Muliadi G.F ini. Semenjak kecil ia telah terbiasa berkumpul dengan pohon-pohon. Namun, ketika menginjak usia sepuluh tahun, ia harus merasakan kehilangan banyak pohon, terutama yang selama ini tumbuh di halaman rumah. Beragam sebab menjadi faktor kematian pohon-pohon tersebut.

Segala puji bagi Allah, Tuhan semesta alam.

"Siapa yang bikin pohon jambu, Pak?" tanya saya suatu malam, di pangkuan bapak, saat kami duduk-duduk di anak tangga. Tiap melihat bapak keluar malam-malam, saya mengikuti sampai teras. Sering dia mengajak saya duduk di tangga, melihat bintang, bulan, apa saja, apa saja...

Tapi sekarang, kedondong juga sudah mati. Ya, mati. Dulu mamak pernah bilang, mati seperti bobok. Pohon kedondong kami sedang bobok. Entah di mana rosbannya, kasurnya, sepreinya, tidak tahulah (Muliadi, 2017). 
Pada paragraf berikutnya, terjemahan ayat kedua surat Al-Fatihah dipergunakan oleh sang penulis, seperti kutipan di atas. Pada suatu kesempatan, Akilah bertanya kepada Bapaknya, siapa pencipta dari segala jenis pohon. Apapun jenis pohon yang ada di halaman rumah ia tanyakan kepada Bapaknya. Tuhan sebagai pencipta segala isi alam juga diceritakan oleh si Bapak kepada Akilah, agar ia memahami kekuasaan Tuhan. Sebuah pelajaran tentang pentignya menjaga lingkungan bagi kemasalahatan manusia. Akilah juga menyayangkan atas kematian pohon kedondong di halaman rumahnya. Pohon yang selama ini menjadi temannya.

Paragraf ketiga sampai kelima juga menggunakan terjemahan ayat ketiga sampai kelimat surat Al-Fatihah. "Maha Pengasih lagi Maha Penyayang" dipergunakan sebagai pembuka pada paragraf ketiga. Tuhan sebagai sosok pengasih serta penyayang bagi seluruh makhluknya. Tuhan menghamparkan bumi sebagai tempat para makhuknya membangun hidup, sebelum kembali lagi kepada-Nya. "Yang menguasai Hari Pembalasan" merupakan terjemahan ayat keempat yang dipergunakan sebagai pembuka pada bagian paragraf keempat cerpen. Pada bagian ini digambarkan tokoh Saya (Akilah) yang rebutan mangga dengan sang kakak (Agil). Namun, saking serakahnya si kakak (Agil), akhirnya ia mengalami sakit perut. Apabila ditarik amanat yang didapat sesuai terjemahan ayat keempat di atas. Bahwa Tuhan akan membalas segala perbuatan, baik itu perbuatan mulai maupun yang tercela. "Hanya Engkau-lah yang kami sembah, dan hanya kepada Engkaulah kami meminta pertolongan" merupakan terjemahan ayat kelima yang dipergunakan oleh sang penulis untuk memulai cerita pada paragraf kelima. Pada bagian tersebut, penulsi menceritakan tokoh Saya (Akilah) yang gemar menanam dan merawat pisang sendiri. Ilmu tersebut diperolehnya dari sang nenek. Pada suatu ketika, ia membawa pisang tersebut ke guru ngajinya 114 | ISSN: 22477-5150, e-ISSN: 2549-2195 http://journal.unesa.ac.id/index.php/jpi 
Wak Latte. Ia ceritakan bahwa telah berhasil menanam pisang dengan hasil memuaskan, namun Wak Latte memberikan pengertian, bahwa semua itu merupakan pertolongan Tuhan yang diberikan kepada kita. Pendidikan moral ekologi yang dikuatkan dengan aspek religius, akan semakin memantapkan upaya pelestarian lingkungan yang selama ini banyak disuarakan.

Pada pargaraf keenam, cerpen Al-Fatihah untuk Pohon-Pohon menggunakan terjemahan ayat keenam Al-Fatihah sebagai pembuka cerita. Semakin banyak pohon yang mati karena beragam penyebab. Setelah berbuah maupun yang belum berbuah, banyak pohon yang mati. Pohon pisang diceritakan oleh tokoh Saya (Akilah) akan mati setelah berbuah. la merasa kasihan, mengapa pohon haruslah tumbang dan mati setelah berbuah. Ada pula pohon yang belum berbuah namun juga megalami kematian. Tokoh Saya (Akilah) menceritakan sebuah pohon kelapa di belakang rumah. la harus mengalami kematian karena ditebang. Pohon tersebut tumbuh dekat sekali dekat dapur tempat sang emak memasak. Alhasil, perkakas dapur acapkali rusak karena pohon kelapa tersebut. Pada bagian ini cerpen memberikan pelajaran hidup, bahwa pohon rela memberikan hasilnya demi kemaslahatan hidup makhluk lain (manusia). Akan tetapi, banyak diantara pohon tersebut justru menjadi korban " rasa tak tahu terima kasih" yang dilakukan oleh sebagain manusia.

Tunjukilah kami jalan yang lurus.

Setelah berbuah, pohon pisang mati. Dia dibuat tumbang demi buahnya. Kadang saya sedih, mengapa pohon mesti mati setelah berbuah?

Tapi, ada juga pohon-pohon yang tidak mati setelah berbuah. Dan ada juga yang mati meski belum berbuah. Ada banyak. Contohnya pohon kelapa di belakang rumah. la 
berdiri dekat sekali dari dapur tempat mamak memasak, sampai-sampai mamak sering terlompat kalau pelepah kelapa jatuh menimpa atap seng, sampai piring yang dipegang mamak jatuh berkeping (Muliadi, 2017).

Pada bagian akhir cerita, cerpen berkisah tentang sikap menghargai kepada siapapun, termasuk nenek yang meninggal pun pohon-pohon yang mati. Tokoh Akilah merasa kehilangan yang sangat dengan kepergian sang nenek yang ditabrak orang tak bertanggung jawab ketika menyebrang jalan. Semenjak itu, Akilah merasa kehilangan dengan neneknya yang mati dan pohon-pohon yang juga ikut mati. Bagian akhir cerita ini menggunakan ayat terakhir surat Al-Fatihah sebagai cerminan isi cerita. Ayat tersebut sebagai berikut, "Jalan orang-orang yang telah Engkau beri nikmat kepada mereka; bukan (jalan) mereka yang dimurkai dan bukan (pula jalan) mereka yang sesat". Semenjak kepergian sang nenek pun pohon-pohon yang ada disekelilingnya, Akilah sering mengirimkan doa Al-Fatihah untuk apapun yang mati. la berharap agar apapun yang mati dapat tenang di sana. Selain sebagai sebuah doa yang menyelamatkan uamat manusia, surat Al-Fatihah juga dipergunakan sebagai simbol rasa terima kasih tokoh Akilah terhadap pohon-pohon yang selama ini hidup dan membawa manfaat besar bagi keluarganya. Hal tersebut tercermin dalam kutipan berikut ini.

Tapi, semua menghibur saya. Bacakan Al-Fatihah untuk nenek supaya dia tenang di alam sana, kata mereka.

Saat itu saya baru tahu semua yang mati perlu dibacakan Al-Fatihah. Saya sudah hafal Al-Fatihah.

Dan, untuk pohon-pohon, saya juga tidak lupa mengirimkan tujuh ayat itu. Saya percaya mereka tumbuh di surga. Di sana mereka berbuah banyak dan besar-besar seperti balon. Barangkali ada anak lain yang lebih dulu makan buah pohon-pohon itu, tapi saya cuek. Saya percaya mereka 
masih menyisakan buah-buah untuk saya. Saya ini teman pohon-pohon (Muliadi, 2017).

Cerpen Al-Fatihah untuk Pohon-Pohon karya Muliadi G.F menjadi semacam cara segar dalam menyajikan fenomena ekologi di karya sastra. Cerpen ini memadukan unsur religiusitas dengan ekologi. Religiusitas bisa menjadi semacam "penguat" ihwal pentingnya menjaga kelestarian lingkungan, meski hanya dimulai dari lingkup kecil. Kesadaran lingkungan memang menjadi fenomena yang cukup sulit untuk di bangun kuat di dalam masyarakat. Melalui karya sastra berbasis ekologi ini (ekokritik), diharapkan kesadaran masyarakat tentang lingkungan jauh lebih meningkat. Apalagi memasukkan aspek keagamaan di dalam membangun cerita. Sayangnya, cerpen ini apabila ditelisik cukup mendalam, hanya masyarakat yang notabene berkepercayaan islam saja yang bisa menikmati. Karena, unsur religiusitas yang dimasukkan dalam cerita hanya dipahami oleh masyarakat muslim saja. Surat Al-Fatihah merupakan surat inti yang terkandung dalam kitab suci umat islam (Al-quran).

Cerpen yang juga memilih jalan cerita tentang ekokritik adalah Pergi ke Bukit karya Tjak S. Parlan. Cerpen yang berkisah tentang tokoh Dali ini pernah dimuat di media massa Republika edisi 4 Juni 2017. Berkisah tentang sebuah keluarga yan terdiri dari ibu (Kayah), bapak (Burhan), serta anak (Dali). Tokoh Dali diceritakan memiliki keinginan untuk merubah kehidupan keluarga, semenjak sang bapak tak pernah kembali dari Malaysia. Di awal cerita, tokoh Dali memiliki keinginan besar untuk dapat bekerja dengan penghasilan yang jauh lebih besar, ketimbang harus berladang bersama si Emak (Kayah). 
Kayah berharap, anak laki- laki satu-satunya masih bisa menemaninya di ladang. Apa lacur, ia tak bisa menahan keinginan anaknya untuk berangkat. Kenyataan itu serupa dengan apa yang dihadapinya setahun lalu saat Dali memutuskan keluar dari sekolah dengan alasan ingin bekerja.

"Mana bisa, Mak, saya punya Honda baru seperti Toni kalau cuma nambal ban?" Kayah teringat percakapan dengan anaknya seminggu yang lalu (Parlan, 2017).

Dali tampak begitu bulat dengan tekatnya untuk bekerja, guna mendapatkan penghasilan yang lebih. Sebenarnya hasil berladang sudahlah cukup untuk makan sehari-hari. Akan tetapi, karena "demam gengsi" yang terjadi di kampungnya, membuat semua orang berbondong-bondong untuk semakin materialistis. Ukuran kebahagiaan bagi sebagai besar warga kampung menjadi bergeser. Kebahagiaan diukur berdasarkan kekayaan materialisme. Apalagi semenjak perbukitan di sebelah kampung diketahui menjadi sumber emas. Warga makin banyak yang berbondong-bondong. Mereka berharap dapat mendapatkan emas sebanyak mungkin, lantas menjadi kaya raya.

Sejak perbukitan di sebelah kampung mereka didatangi orang-orang dari berbagai tempat, warga di kampungnya pun berduyun-duyun ke sana. Orang-orang melubangi bukit itu untuk mencari emas. Mereka akan berada di sana selama berpekan-pekan dan hanya pulang mengambil bahanbahan makanan untuk bekal berikutnya selama di bukit. Beberapa yang beruntung akan menyempatkan diri ke kota dan belanja lebih banyak, membelikan ini itu untuk ke luarganya di rumah. Sementara, yang lainnya, yang belum beruntung, tak ada pilihan lain selain cepat-cepat kembali ke bukit dengan harapan bahwa berikutnya merekalah yang akan mendulang emas (Parlan, 2017). 
Bahkan dalam kutipan di atas digambarkan bahwa warga tak kenal lelah untuk mendulang emas sebanyak-banyaknya dari perbukitan tersebut. Ini menjadi penanda keserakahan warga kampung di daerah Dali. Mereka tergiur dengan kekayaan yang diperoleh dengan cara mudah seperti itu. Warga kampung juga digambarkan tak menaruh perhatian terhadap kelestarian lingkungan. Mereka hanya mengambil dengan serakah terhadap kekayaan alam yang ada. Karya sastra dalam posisi ini menjadi ruang untuk memberikan pembelajaran moral, khususnya ihwal lingkungan kepada masyarakat luas. Apalagi saat ini degradasi lingkungan karena sikap serakah manusia makin mengkhawatirkan. Diperlukan adanya langkah preventif terhadap fenomena yang amat mengancam keberlangsungan hidup umat manusia tersebut. Salah satunya melalui sarana karya sastra (cerpen).

Kayah menatap sekeliling ke ladang-ladang tetangga. Semak-semak bertumbuhan di sana-sini. Beberapa ekor kerbau merumput di antaranya. Dulu-dulu, ia jarang melihat pemandangan seperti ini. Ladang-ladang selalu tergarap pada waktunya. la bisa melihat benih-benih palawija yang mulai tumbuh, menghijau daun-daunnya, aneka warna bunganya dan biji-bijinya yang bernas. Namun, sejak di bukit ditemukan batu-batu yang, katanya, bisa disulap jadi emas, ladang-ladang mulai kehilangan penggarapnya. Semakin banyak laki-laki yang pergi ke bukit, meski satu dua di antara mereka ada yang tidak kembali. Sementara itu, para perempuan melakukan apa saja yang mereka bisa: memasak untuk anak-anak dan orang-orang tua yang di rumah; menggembalakan sapi atau kerbau piaraan di ladang-ladang mereka yang terbengkalai (Parlan, 2017).

Makin banyak ladang terbengkalai serta tak terurus. Sebagian besar di antara warga desa memilih pergi ke bukit. Mengikis bukit besar-besaran, lalu mencoba meraih peruntungan dengan mendulang emas yang konon 
begitu banyak tersebar di bukit. Kerusakan lingkungan terjadi dengan tak terkendali. Bukit yang harusnya menjadi penyeimbang alam, semakin terkikis keberadaannya. Ketamakan sikap warga tergambar di dalam kutipan di atas. Mereka sudah tak peduli dengan kerusakan yang mungkin terjadi serta akibat yang harus ditanggung. Keuntungan material semata yang mereka harapkan. Padahal, keberlangsungan hidup anak cucu juga tergantung dengan ekistensi lingkungan.

Kisah dalam cerpen Pergi ke Bukit makin tragis, ketika Dali ditemukan tewas tertimbun longsoran bukit. Sebenarnya sudah berulang kali tragedi semacam itu terjadi. Akan tetapi, sikap warga yang tak acuh terhadap lingkungan serta gengsi yang besar, membuat mereka tak pernah berhenti untuk terus menggali bukit. Kepergian Dali menjadi puncak konflik yang terjadi dalam cerpen ini. Kematiannya menjadi pembelajaran moral, bahwa sikap bersyukur serta tidak tamak menjadi kunci kebahagian manusia. Hal tersebut menjadi indikator bahwa manusia semacam itu memiliki rasa terima kasih yang tinggi atas segenap pemberian dari Tuhan kepada mereka. Kisah kematian Dali tertangkap dalam kutipan berikut.

Seseorang yang mewakili rombongan itu segera beringsut, tangannya menyingkap selembar kain yang menutupi sesosok jasad di tengah-tengah ruangan itu. "Kami semua warga kampung ini. Kami sangat mengenal anakmu," katanya kemudian.

Kayah terperangah melihat sebentuk wajah yang sangat dikenalnya itu. Antara percaya dan tidak, Kayah meraih tubuh tak berdaya itu seraya menggoncang-goncangnya berkali-kali. Kayak menjerit sejadi-jadinya (Parlan, 2017).

Cerpen Pergi ke Bukit karya Tjak S. Parlan menjadi sebuah terobosan, utamanya dalam misi penyelamatan lingkungan melalui sarana karya sastra. 
Ekokritik memberikan tempat bagi siapapun yang ingin menghadirkan unsur ekologi dalam menciptakan karya sastra, salah satunya dalam bentuk cerpen. Unsur tragedi yang terjadi di dalam isi cerita memiliki pengaruh yang cukup kuat untuk mengaduk emosi para pembaca. Sayangnya, unsur "akibat" yang harus dirasakan sebagai dampak dari ulah tak bertanggung jawab terhadap alam tersebut hanya diterima oleh keluarga Dali saja. Warga desa lain yang juga ikut terlibat dalam upaya mengeksploitasi bukit tidak diceritakan dengan jelas di dalam isi cerpen. Harusnya poin tersebut juga dapat diperhatikan. Sehingga akan membawa pembaca pada suasana tragedi yang kuat, namun tetap tidak meninggalkan fokus isi cerita. Akan tetapi, cerpen Pergi ke Bukit ini secara umum amat layak dipergunakan sebagai sarana pendidikan lingkungan.

Pertunjukan Hari Ketujuh karya S.Prasetyo Utomo merupakan salah satu cerpen yang mengangkat aspek ekokritik didalamnya. Garis besar isi cerita hampir serupa dengan kasus pabrik semen di daerah Pegunungan Kendeng, Rembang, Jawa Tengah yang sempat menjadi isu nasional. Cerpen tersebut berkisah tentang tokoh Kodrat yang melakukan pertunjukan bersama warga desanya dalam rangka menemui presiden. Pertemuan tersebut amat diharapkan oleh Kodrat serta warga. Mereka menghendaki penutupan pabrik semen yang tengah di bangun di lembah Gunung Bokong. Warga berpendapat bahwa pembangunan tersebut akan menimbulkan kerusakan lingkungan, sehingga mereka akan kehilangan sawah yang menjadi sumber kehidupan selama ini. Penulis cerpen Pertunjukan Hari Ketujuh sepertinya memang memanfaatkan garis besar kasus Semen Kendeng yang tengah menjadi perbincangan untuk diadopsi ke dalam cerpen karangannya. Karena memang secara isi cerita, hampir serupa 
dengan permasalahan di daerah Rembang tersebut. Perjuangan awal tokoh Kodrat beserta warga dalam upaya penyelamatan ekologi daerah lembang Gunung Bokong tergambar dalam kutipan berikut.

Kodrat ingin mengatakan semuanya kepada presiden bahwa pabrik semen yang didirikan di lembah Gunung Bokong merusak alam di daerah kapur itu, mematikan mata air, dan menghancurkan bumi tempat mereka bertani. la, mewakili kehendak warga, menyampaikan pesan agar pabrik semen itu segera ditutup (Utomo, 2017).

Kodrat hanya berharap kepada presiden sebagai kepala negara untuk ikut turun tangan menghentikan eksploitasi kekayaan alam didesanya. Mereka begitu berharap besar terhadap kemurahan hati presiden. Meskipun harus menunggu kehadiran presiden dalam beberapa hari. Dalam posisi ini, sastra menjadi sarana untuk menumbuhkan kepedulian terhadap pentingnya menjaga lingkungan beserta segenap kehidupan yang ada didalamnya. Bukan berarti tidak manusia tidak diperbolehkan sama sekali untu mengambil hasil alam yang telah diberikan oleh Tuhan. Akan tetapi, sikap bertanggung jawa serta tetap memperhatikan kepedulian lingkungan menjadi poin penting yang harus dilakukan oleh seluruh umat manusia.

Sesekali Kodrat menghibur hati teman-temannya, yang merindukan pulang kembali ke lembah Gunung Bokong, teringat akan rumah yang luas, ladang dan sapi-sapi piaraan mereka. Teman-teman yang lain teringat akan istri, lantaran mereka baru saja menikah. Yang lain lagi teringat akan anak yang lagi lucu-lucunya belajar bicara, berjalan tertatih-tatih. Kodrat cemas berharap Kiai Bisri segera menyusul ke istana negara, merestui pergelaran mereka. Kehadiran Kiai Bisri diharap akan mengundang presiden untuk turun dari istana negara, dan bertanya, "Apa yang Saudara tuntut dariku?" (Utomo, 2017). 
Nyatanya, perjuangan Kodrat beserta warga bukanlah hal yang mudah. Banyak diantara warga yang hampir patah semangat, melanjutkan misi menemui presiden guna memohon agar pabrik semen yang didirikan di lembah Gunung Bokong segera ditutup. Mereka begitu khawatir dengan dampak lingkungan yang dapat terjadi. Terutama yang berkaitan dengan masa depan lahan pertanian mereka. Persawahan telah menjadi nafas kehidupan serta bagian dari kebudayaan masyarakat lembah Gunung Bokong. Perjuangan tersebut dapat dilihat dalam kutipan di atas. Selain itu, tokoh Kodrat juga amat menantikan kehadiran Kyai Bisri. Tokoh ini dianggap dapat melobi pertemuan dengan presiden. Pertemuan yang memang mahal harganya bagi sebagai besar warga lembah Gunung Bokong.

Ironi juga terjadi di dalam cerpen karangan S.Prasetyo Utomo ini. Lurah Karso beserta anak buahnya merupakan beberapa oknum yang tidak mendukung terhadap upaya penyelamatan lingkungan yang dilakukan Kodrat beserta kawan-kawan. Lurah Karso beserta anak buahnya justru menghendaki pembangunan pabrik semen didaerah Gunung Bokong. Sebuah ironi, aparatur pemerintahan yang harusnya berdiri di garda terdepan memperjuangkan kelestarian lingkungan, malah menjadi pemicu kerusakan lingkungan didaerahnya. Motif ekonomi menjadi pokok utama tujuan pilihan mereka. Padahal sudah jelas, sikap tersebut tidaklah layak untuk dilakukan. Apalagi pada saat bersamaan, sebagain besar warga mempertaruhkan segalanya demi keselamatan lingkungan mereka dari kerusakan.

Melintasi jalan raya yang tengah dibenahi, anak buah Lurah Ngarso -yang sangat mendukung pendirian pabrik semenmenyoraki mereka dengan seruan kasar dan caci-maki. 
Kodrat menahan diri. Tak membalas cemoohan mereka yang tengah mengatur mobil-mobil yang lalu-lalang.

"Biar kuhajar mulut mereka!" kata sopir truk, yang bertubuh kekar dan sigap. Kodrat tersenyum, meredakan kemarahan sopir truk. Di tepi jalan kian banyak didirikan warung makan yang menerima para pekerja proyek pabrik semen dan mereka mencemooh truk yang ditumpangi Kodrat berangkat ke ibu kota (Utomo, 2017).

Sastra hadir sebagai spirit tentang kemanusiaan. Membangkitkan nilai tentang pentingnya menjunjung nilai-nilai menghargai sesama manusia. Upaya Kodrat, warga serta Kyai Bisri untuk memperjuangkan tanah kelahiran mereka dari kerusakan lingkungan, pada akhirnya berbuah kebahagiaan pun kedukaan. Istri Kyai Bisri meninggal dunia. Kyai Bisri yang tengah membantu perjuangan warga lembah Gunung Bokong haruslah merelakan kepergiaan sang istri. Inilah aspek moral yang penting serta membawa nilai positif dari sebuah karya sastra, apabila ditelisik secara mendalam kandungan pendidikan didalamnya. Ajaran moral tentang kegigihan pengorbanan menyelamatkan lingkungan tergambar dalam kutipan berikut.

Alangkah senyap. Tubuh Kodrat bergetar. Tentu ini berita tentang Nyai Bisri, yang telah meminta kiai untuk menemui Kodrat di depan istana negara.

Kodrat dan empat orang lembah Gunung Bokong yang setia, meneruskan zikir mereka di atas truk terbuka. Terus berzikir dengan tubuh terguncang-guncang selama lebih dua belas jam perjalanan dari ibu kota menuju lembah Gunug Bokong. Tidak. Mereka tidak pulang ke sana. Menjelang dini hari mereka singgah di pesantren Kiai Bisri. Terus berzikir di depan jenazah Nyai Bisri. Zikir yang lirih dan jernih. Zikir yang tak merintih (Utomo, 2017). 
Secara umum, cerpen Pertunjukan Hari Ketujuh ini telah mampu memberikan persepsi yang kuat terhadap upaya penyelamatan lingkungan melalui sarana sastra (ekokritik). Muatan pendidikan juga digelorakan dengan kuat dalam tiap alur cerita. Sikap sederhana serta bersyukur atas pemberian Tuhan juga menjadi salah satu aspek pendidikan moral didalamnya. Moral dalam karya sastra mencerminkan pandangan hidup pengarang yang bersangkutan, oleh sebab itu moral dalam karya sastra dapat dipandang sebagai amanat, pesan, massage yang ingin disampaikan kepada pembaca (Dirgantara, 2012:99). Sayangnya, konsekuensi dari sikap tokoh Lurah Karso beserta anak buah kurang dieksploitasi mendalam. Poin ini penting kiranya untuk dikembangkan. Pembaca akan menarik pelajaran moral melalui perbandingan antara tokoh pro lingkungan dengan yang kontra terhadap pelestarian lingkungan. Pembaca akan memiliki persepsi yang makin kuat, utamanya untuk bersikap jauh lebih bijak dalam memanfaatkan sumber daya alam yang telah dianugerahkan.

\section{SIMPULAN}

Ekokritik memberikan perhatian terhadap hubungan timbal balik antara karya sastra dengan lingkungan hidup, termasuk hubungan dengan realitas sosial budaya dan fisik, yang biasanya menjadi perhatian dalam ekologi (Endraswara, 2016: viii). Sastra pada perkembangannya menjadi sarana untuk menyampaikan misi pendidikan lingkungan kepada masyarakat luas. Tugas ranah pendidikan: memusnahkan dampak lingkaran keterbelakangan yang negatif dan menciptakan lingkaran positif (Surakhmad, 2009:17). Beragam karya sastra, seperti puisi, cerpen, novel, pantun, maupun naskah drama dapat menjadi alat pendidikan ekologi 
tersebut. Memang terdapat beragam alternatif dalam mengatasi problematika lingkungan hidup, namun sastra mampu menjadi salah satu terobosan guna membentuk manusia yang humanis terhadap kelestarian lingkungannya.

Ekokritik tersebut juga hadir dalam ragam karya cerpen Indonesia mutakhir. S.Prasetyo Utomo dengan cerpen Pertunjukan Hari Ketujuh menghadirkan kisah tentang perjuangan Kodrat beserta para warga dalam upaya menolak pendirian pabrik semen di daerah lembah Gunung Bokong. Pendirian pabrik semen tersebut dianggap oleh warga akan berkontribusi terhadap kerusakan lingkungan serta hilangnya mata pencaharian warga sebagai petani. Adi Zamzam dengan cerpen Rob mengisahkan tentang banjir rob di daerah Semarang Utara yang tak pernah usai. Banji rob ini muncul tak lain karena ulah manusia yang tak memperhatikan keseimbangan lingkungan. Beragam bangunan didirikan di daerah resapan air. Alhasil, malapetaka rob tak pernah usai di Semarang Utara. Tjak S.Parlan menceritakan tentang obsesi warga suatu desa yang begitu mendambakan kekayaan harta sebagai kunci kebahagiaan. Melalui cerpen Pergi ke Bukit, pengarang menceritakan tokoh Dali yang memiliki obsesi besar untuk kaya raya dengan menggali serta menambang emas di sebuah bukit dekat desa. Harapan itu akhirnya sirna, Dali ditemukan tewas tertimbun material bukit. Keserakahan manusia terhadap alam akan membawa bencana terhadap diri sendiri maupun keluarga. Muliadi G.F dengan cerpen Al-Fatihah untuk Pohon-Pohon berkisah tentang seorang anak yang merasa begitu bersahabat dengan pohon-pohon. Suatu ketika, ia menyadari semakin banyak pohon di halaman rumahnya yang mati karena beragam sebab. Tak cuma pohon-pohon, ia juga kehilangan sang nenek karena tertabrak kendaraan di suatu hari. Demi "memberkati" kehilangan dalam hidupnya 126 | ISSN: 22477-5150, e-ISSN: 2549-2195 http://journal.unesa.ac.id/index.php/jpi 
tersebut, sang anak melantukan surat Al-Fatihah, mendoakan keselamatan pohon-pohon serta neneknya.

Beragam nilai pendidikan tertuang baik secara implisit pun eksplisit. Sastra dijadikan sebagai media untuk menyampaikan ide-ide, pikiranpikiran, dan pandangan-pandangan sehubungan misi yang diemban: mendidik rakyat (Alwi dan Sugono, 2002:228). Masing-masing cerpen dikemas dengan gayanya sendiri. Setiap karya membawa misi yang berbeda. Akan tetapi, gambaran karya cerpen Indonesia mutakhir tersebut tetaplah dalam satu kerangka, yaitu pendidikan tentang ekokritik.

\section{DAFTAR RUJUKAN}

Alwi, Hasan. Sugono, Dendy (Ed). 2002. Telaah Bahasa dan Sastra. Jakarta: Yayasan Obor Indonesia.

Dewi, Irra Chrisyanti. 2015. Pengantar Psikologi Media. Jakarta: Prestasi Pustakarya.

Dirgantara, Yuana Agus. 2012. Pelangi Bahasa Sastra dan Budaya Indonesia: Kumpulan Apresiasi dan Tanggapan. Yogyakarta: Garudhawaca Digital Book and POD.

Drummond, Celia Deane. 2006. Teologi dan Ekologi: Buku Pegangan. Jakarta: Gunung Mulia.

Endraswara, Suwardi (Ed.). 2016. Sastra Ekologis Teori dan Praktik Pengkajian. Yogyakarta: CAPS (Center for Academic Publishing Service). 
G.F, Muliadi. 2017. Al-Fatihah untuk Pohon-Pohon: Cerpen Muliadi G.F. (Online). (https://lakonhidup.com/2017/04/30/al-fatihah-untukpohon-pohon/). diakses 2 Agustus 2017.

Garrard, Greg. 2004. Ecocriticism. New York: Routledge.

K.S, Yudiono. 2009. Pengkajian Kritik Sastra Indonesia. Semarang: PT. Grasindo.

Kresna, Sigit B (Ed). 2001. Mengenal Lebih Dekat: Putu Wijaya Sang Teroris Mental dan Pertanggungjawaban Proses Kreatifnya. Jakarta: Yayasan Obor Indonesia.

Liliweri, Alo. 2002. Makna Budaya dalam Komunikasi Antar Budaya. Yogyakarta: PT. LKiS Pelangi Aksara.

Moleong, Lexy J. 2005. Metodologi Penelitian Kualitatif. Bandung: Remaja Rosdakarya.

Parlan, Tjak S. 2017. Pergi ke Bukit: Cerpen Tjak S. Parlan. (Online). (https://lakonhidup.com/2017/06/04/pergi-ke-bukit/). diakses 2 Agustus 2017.

Priyo. 2015. Keutamaan dan Isi Kandungan Surat Al-Fatihah. (Online). (http://ilmutafsir.com/blog/keutamaan-dan-isi-kandungan-surat-alfatihah). diakses 23 Juli 2017.

Sarumpaet, Riris K. Toha dan Budianta, Melani. 2010. Rona Budaya: Festschrift untuk Sapardi Djoko Damono. Jakarta: Yayasan Pustaka Obor Indonesia.

Surakhmad, Winarno. 2009. Pendidikan Nasional-Strategi dan Tragedi. Jakarta: PT. Kompas Media Nusantara.

Utomo, S.Prasetyo. 2017. Pertunjukan Hari Ketujuh: Cerpen S.Prasetyo Utomo. (Online). 
Afry Adi Chandra, Eko Kritik dalam Cerpen...(hal. 100 - 129)

(https://lakonhidup.com/?s=Pertunjukan+Hari+Ketujuh+). diakses 2 Agustus 2017

Zamzam, Adi. 2017. Rob: Cerpen Adi Zamzam. (Online). (https://lakonhidup.com/2017/07/02/rob/). diakses 2 Agustus 2017. 